\title{
Osteomalacia and renal failure due to Fanconi syndrome caused by long-term low-dose Adefovir Dipivoxil: a case report
}

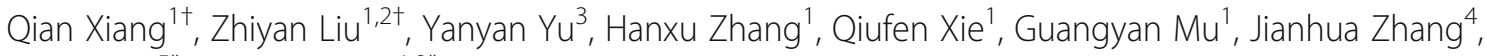
Xinan Cen $^{5^{*}}$ and Yimin Cui ${ }^{1,2^{*}}$ (i)

\begin{abstract}
Background: Progressive bone pain and fracture and abnormal positron emission tomography combined with a computed tomography are main reasons for the oncologists suspecting bone tumor. During the patient's medical treatment, the oncologists' unfamiliarity with adverse reactions to anti-HBV drugs were main reason for the longterm exposure to the drug and the adverse reaction (ADR) experienced by the patient.

Case presentation: A 63-year-old Chinese man had a 27-month history of progressive generalized bone pain combined with spontaneous fractures. Positron emission tomography combined with a computed tomography, revealed an abnormal increase in ribose metabolism and low positron serum inorganic phosphorus concentration $(0.7 ; 0.78-1.65 \mathrm{mmol} / \mathrm{L})$. Serum creatinine level was $252 \mu \mathrm{mol} / \mathrm{L}(53-97) \mu \mathrm{mol} / \mathrm{L}$, and glomerular filtration rate was $22.79 \mathrm{~mL} / \mathrm{min} / 1.73 \mathrm{~m}^{2}$. The patient was referred to a multidisciplinary clinic to clarify the diagnosis of myeloma or bone tumor for further treatment in 2017. His medical history revealed that he had a 30-year history of chronic hepatitis B infection. He had received lamivudine at a daily dose of $100 \mathrm{mg}$ for 19 years (1990 to 2009), which had been changed to adefovir (10 mg/day) owing to lamivudine resistance in 2009. Based on the changes in the patient's laboratory markers and the results of emission computed tomography and other radiographic findings, adefovir-induced hypophosphatemic osteomalacia due to acquired renal Fanconi syndrome was suspected by the clinical pharmacist. Considerable clinical improvement was observed after adefovir discontinuation and the administration of entecavir (1.0 mg, every other day).
\end{abstract}

Conclusion: Fanconi syndrome with osteomalacia can develop in patients with chronic hepatitis B infection being treated with adefovir at a conventional low dosage of $10 \mathrm{mg} /$ day. This case highlights the importance of ADR as a differential diagnosis and the need of pharmacists with drug safety expertise expert in the patient management.

Keywords: Adefovir dipivoxil, Fanconi's syndrome, Osteomalacia, Case report

\footnotetext{
* Correspondence: cenxn@bjmu.edu.cn; cui.pharm@pkufh.com

${ }^{\dagger}$ Qian Xiang and Zhiyan Liu contributed equally to this work.

${ }^{5}$ Department of Hematology, Peking University First Hospital, No. 6,

Dahongluochang Street, Xicheng District, Beijing 100034, China

'Department of Pharmacy, Peking University First Hospital, No. 6,

Dahongluochang Street, Xicheng District, Beijing 100034, China

Full list of author information is available at the end of the article
}

(c) The Author(s). 2020 Open Access This article is licensed under a Creative Commons Attribution 4.0 International License, which permits use, sharing, adaptation, distribution and reproduction in any medium or format, as long as you give appropriate credit to the original author(s) and the source, provide a link to the Creative Commons licence, and indicate if changes were made. The images or other third party material in this article are included in the article's Creative Commons licence, unless indicated otherwise in a credit line to the material. If material is not included in the article's Creative Commons licence and your intended use is not permitted by statutory regulation or exceeds the permitted use, you will need to obtain permission directly from the copyright holder. To view a copy of this licence, visit http://creativecommons.org/licenses/by/4.0/ The Creative Commons Public Domain Dedication waiver (http://creativecommons.org/publicdomain/zero/1.0/) applies to the data made available in this article, unless otherwise stated in a credit line to the data. 


\section{Background}

Chronic hepatitis B virus (HBV) infection, affecting an estimated 257 million people [1], become one of the most common infectious diseases and a leading cause of liver-related death worldwide. Furthermore, the updated treatment guidelines for chronic HBV management specified that patients had decreased renal function and bone mineral density for a long-term treatment with certain anti-HBV medications [2]. Studies found an association between chronic HBV and renal injury, and increased risk of osteoporosis relative to non-chronic HBV controls [3]. Adefovir dipivoxil (ADV), is an orally bioavailable prodrug of adefovir, used for the management chronic hepatitis B. High-dose ADV therapy of 60$120 \mathrm{mg} /$ day is nephrotoxic and associated with significant rates of renal dysfunction, low-dose ADV of $10 \mathrm{mg} /$ day was reported to be safe [4]. An increasing number of reports stated that use of low-dose ADV for long time caused proximal renal tubular dysfunction, especially in East Asian populations [5-9]. However, at present, there are few cases of renal dysfunction and bone pain caused by adefovir dipivoxil misdiagnosed as cancer or bone tumor, so this article is worthy of clinical reference.

Here, we reported a patient with 27-month history of progressive generalized bone pain combined with spontaneous fractures, who had been suspected as bone tumors or myeloma. Finally, this case was diagnosed by a multidisciplinary clinic as severe hypophosphatemia osteomalacia and renal Fanconi syndrome induced by low-dose ADV.

\section{Case presentation}

\section{Suspected tumor}

In September 2014, the patient developed bone fractures and pain in his bilateral rib cage and ankles and consulted several hospitals to explore what cause the pain.
The results of the relevant blood and urine examinations during this period were shown in Table 1. Bone marrow aspiration result showed that the bone marrow was approximately normal. Positron emission tomography combined with a computed tomography (PET/CT) showed increased glucose metabolism in the fifth and seventh ribs and T2 spinous processes on the right side of the body. Based on the PET-CT results, and the probably missed diagnosis of bone tumors due to the location of the bone puncture, a clinical diagnosis of adnexal thoracic tumors was suspected by oncologists. This diagnosis was mainly due to diagnostic method limitation. Based on this diagnosis, posterior adnexal thoracic tumor resection, reconstruction, and internal fixation was performed in the patient's local hospital in November 2014. Pathological biopsy was performed on the surgical tissues, and the result was as follows: chest-2-appendix hyperplasia, degeneration of cartilage and ligamentum flavum, broken bone trabeculae and bone marrow tissue, trabecular serous fat atrophy, focal hemangiomatous hyperplasia with sinus dilatation. Postoperative pathology showed no tumor cells.

After surgery, the patient's bone pain remained and aggravated progressively, and renal function was still poor. Urine and creatinine clearance levels were found to be $9.74 \mathrm{mmol} / \mathrm{L}(3.2-8.2 \mathrm{mmol} / \mathrm{L})$ and $180.5 \mu \mathrm{mol} / \mathrm{L}$ (53-97 $\mu \mathrm{mol} / \mathrm{L})$, respectively. Because bone marrow aspiration results were negative in 2014, bone marrow biopsy and bone mineral density (BMD) were performed again in 2016 in order to exclude the possibility of bone tumor deterioration. The results of the 2016 bone marrow aspiration showed that the bone marrow was approximately normal: the proliferation of granulocytes was erratic; the proportion and morphology of cells in promyelocytes and the following stages were almost

Table 1 Blood and urine examination results, 2014

\begin{tabular}{lll}
\hline Parameters & Results & Reference Range \\
\hline Alpha-fetoprotein & 2.9 & $0-20 \mathrm{ng} / \mathrm{mL}$ \\
Carcinoembryonic antigen & 2.41 & $0-6.5 \mathrm{ng} / \mathrm{mL}$ \\
Carbohydrate antigen199 & 7.6 & $0-37 \mathrm{u} / \mathrm{mL}$ \\
Prostate specific antigen & 0.15 & $0-4 \mathrm{ng} / \mathrm{mL}$ \\
Carbohydrate antigen 125ll & 5.6 & $0-35 \mathrm{u} / \mathrm{mL}$ \\
Carbohydrate antigen - 724 & 1.18 & $0-8.2 \mathrm{u} / \mathrm{mL}$ \\
Squamous cell carcinoma-associated antigen & 1.94 & $0-2.5 \mathrm{ng} / \mathrm{mL}$ \\
PTH (parathyroid hormone) & 24.4 & $16-87 \mathrm{pg} / \mathrm{mL}$ \\
Serum light chain $\lambda$ (b $\lambda$-LC) & 2.01 & $0.9-2.1 \mathrm{~g} / \mathrm{L}$ \\
Serum light chain K (bK-LC) & 1.65 & $1.7-3.7 \mathrm{~g} / \mathrm{L}$ \\
Hemoglobin (HGB) & 138 & $130-175 \mathrm{~g} / \mathrm{L}$ \\
Urue & $8.5 \uparrow$ & $3.2-8.2 \mathrm{mmol} / \mathrm{L}$ \\
Serum creatinine level & $154.8 \uparrow$ & $53-97 \mathrm{umol} / \mathrm{L}$ \\
Phosphorus & $0.71 \downarrow$ & $0.78-1.65 \mathrm{mmol} / \mathrm{L}$ \\
\hline
\end{tabular}


normal; erythrocyte proliferation was active, mainly in the middle and late stages of erythrocyte proliferation, and there was no obvious abnormality in morphology; lymphocytes accounted for $33 \%$ of the total blood count, and their morphology was normal; megakaryocytes were also normal. In addition, dual-energy X-ray absorptiometry showed a decreased lumbar spine BMD of 0.817 $\mathrm{g} / \mathrm{cm}^{2}$ (T-score, -2.4 ) and a total BMD of $0.729 \mathrm{~g} / \mathrm{cm}^{2}$ (T-score, -2.0$)$ ( $\mathrm{T}$ T-score $<-2.5$, normal $>1.0$ ). The BMD test results are shown in Fig. 1 and Table 2.

Computed tomography and magnetic resonance imaging of the thoracolumbar spine revealed multiple thoracolumbar compression fractures, bilateral multiple rib fractures with calluses, and right iliac wing fractures with calluses. However, serum inorganic phosphorus concentration was low $(0.7 \mathrm{mmol} / \mathrm{L} ; 0.78-1.65 \mathrm{mmol} / \mathrm{L})$, alkaline phosphatase (ALP) level was significantly high (161.7; $45-129 \mathrm{IU} / \mathrm{mL})$; urine was $9.23 \mathrm{mmol} / \mathrm{L}(3.2-8.2$ $\mathrm{mmol} / \mathrm{L})$, creatinine level was $252 \mu \mathrm{mol} / \mathrm{L}(53-97 \mu \mathrm{mol} /$ $\mathrm{L})$, and eGFR was $22.79 \mathrm{~mL} / \mathrm{min} / 1.73 \mathrm{~m}^{2}$.

Gene detection was conducted to exclude cancerrelated diseases in May 2016. This included detection of Ig gene rearrangement, T-cell receptor gene rearrangement, L256P mutation in the myeloid differentiation factor 88 (MyD88) gene, and qualitative detection of $\mathrm{BCL} /$ $\mathrm{JH}$ gene rearrangement. However, no genetic cause of bone pain was found, and the pain gradually increased in October 2016. In order to seek further treatment, the patient was referred to the hematology department of the Peking University People's Hospital, and was recommended by the doctors to visit the multidisciplinary clinic of our hospital. From 2014 to 2016, the patient suffered from bone pain, which he described as 'physical torture', and paid about 300,000 RMB in economic expenses, excluding medical insurance reimbursement and transportation costs.

\section{Multidisciplinary teams and diagnosis of adverse drug reaction}

Over the last two decades, referral to the multidisciplinary team (MDT) has become routine procedure in our center, especially for patients with difficult miscellaneous diseases. Clinical pharmacists have begun to participate in the multidisciplinary outpatient clinics in the hematology department since 2016. In January 2017, a patient came to our MDT clinic with 27-month history of progressive generalized bone pain involving severe chest and wall pain, pain in the hips, knees, ankles, and heels. He wanted to explore the reason for his bone pain and discuss further treatment. Physical examination showed tenderness in the middle and back of thoracic vertebrae, both sides of sacroiliac joint, medial side of knee joint and anterior chest wall, with slight spot edema. The neurological symptoms were negative. No stromas were palpable. No specific signs were found in the respiratory, digestive, or circulatory systems. No edema was found in the patient's legs. No clinical evidence of an infectious, inflammatory, or malignant process were found. Therefore, systemic diseases were excluded. Other related markers, including immunoglobulins tested using immunofixation electrophoresis (IgG/A/M/D), alpha-fetoprotein from 2014 to 2019, were negative (Table 3). Endoscopy did not reveal any mass in the esophagus, stomach or colon. Bone marrow aspiration was normal. Therefore, bone tumors, bone metastasis, or other systemic disease were excluded. The

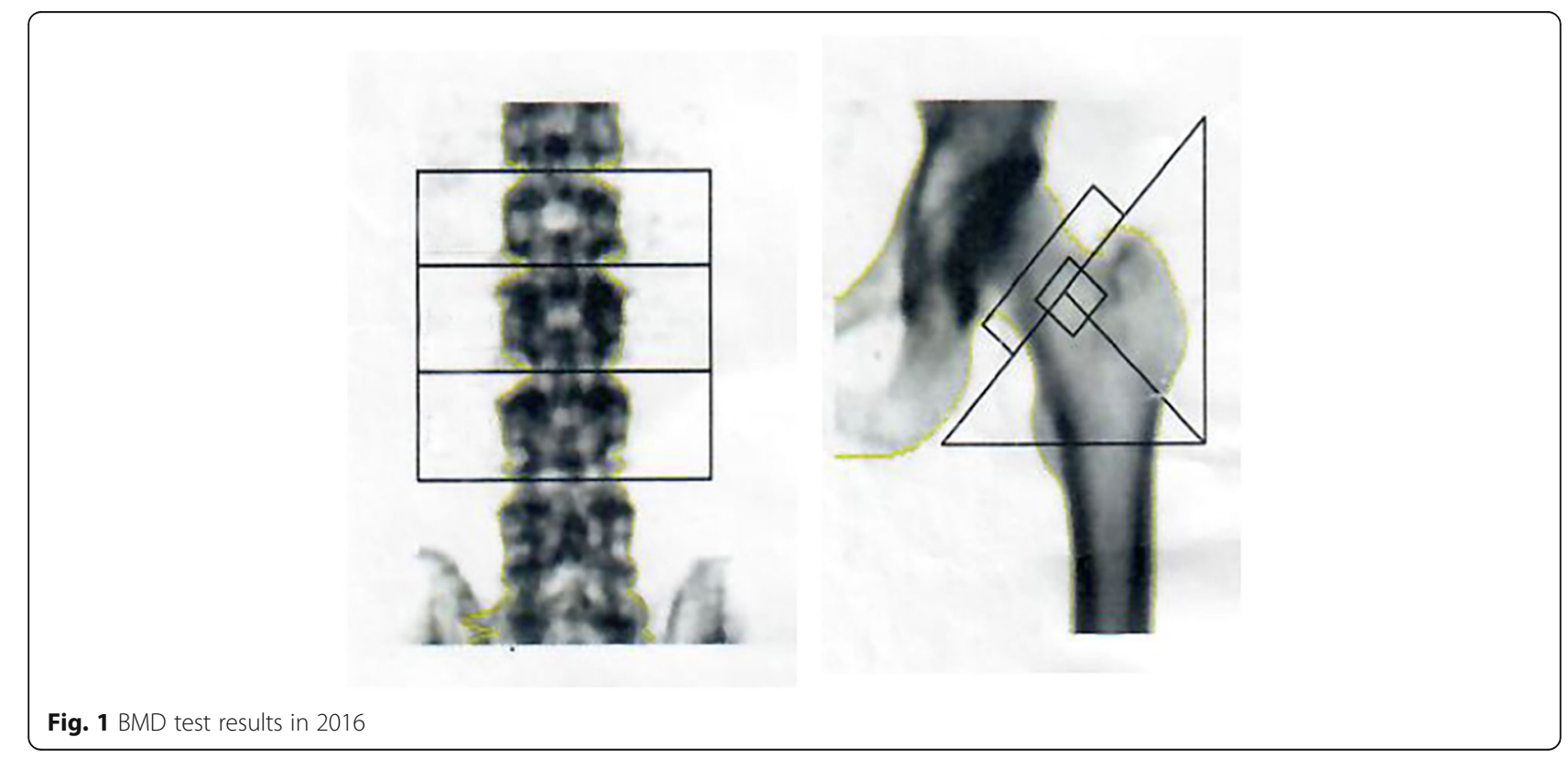


Table 2 Bone mineral density test results (T score $<-2.5$, normal $>1.0$ ) in 2016

\begin{tabular}{llll}
\hline Position & Bone mineral density $(\mathrm{g} / \mathrm{cm} 2)$ & T-score of young people & Z-score for normal population of the same age \\
\hline Lumbar spine 2 & 0.698 & -3.3 & -2.5 \\
Lumbar spine 3 & 0.886 & -1.9 & -1.2 \\
Lumbar spine 4 & 0.847 & -2.0 & -1.6 \\
Lumbar spine2-Lumbar spine4 & 0.817 & -2.4 & -1.7 \\
Neck & 0.728 & -1.9 & -0.9 \\
Triangle of Ward & 0.538 & -2.3 & -1.0 \\
Greater trochanter & 0.632 & -1.6 & -1.1 \\
Femoral shaft & 0.808 & $/$ & $/$ \\
Whole & 0.729 & -2.0 & -1.6 \\
\hline
\end{tabular}

Table 3 Results of various blood and markers tests from 2014 to 2019

\begin{tabular}{|c|c|c|c|c|c|c|c|c|c|c|c|c|c|c|c|}
\hline \multirow[t]{2}{*}{ Time } & $\mathrm{AFP}^{\mathrm{a}}$ & $\lg G^{a}$ & $\lg M^{a}$ & $\lg A^{a}$ & $\mathrm{ALT}^{\mathrm{a}}$ & $\mathrm{AST}^{\mathrm{a}}$ & $A L P^{a}$ & $\begin{array}{l}\mathrm{LDH}- \\
\mathrm{L}^{\mathrm{a}}\end{array}$ & $T P^{a}$ & $\mathrm{ALB}^{\mathrm{a}}$ & URUE & $C R^{a}$ & $\mathrm{HGB}^{\mathrm{a}}$ & $\mathrm{Ca}^{\mathrm{a}}$ & $P^{a}$ \\
\hline & $\begin{array}{l}0-20 \\
\mathrm{ng} / \mathrm{mL}\end{array}$ & $\begin{array}{l}6.94- \\
16.2 \mathrm{~g} / \mathrm{L}\end{array}$ & $\begin{array}{l}0.6- \\
2.63 \mathrm{~g} / \\
\mathrm{L}\end{array}$ & $\begin{array}{l}0.68- \\
3.78 \mathrm{~g} / \mathrm{L}\end{array}$ & $\begin{array}{l}0-40 \\
\mathrm{u} / \mathrm{L}\end{array}$ & $\begin{array}{l}0-34 \\
u / L\end{array}$ & $\begin{array}{l}45-129 \\
\mathrm{IU} / \mathrm{mL}\end{array}$ & $\begin{array}{l}90- \\
250 \mathrm{u} / \\
\mathrm{L}\end{array}$ & $\begin{array}{l}60- \\
80 \mathrm{~g} / \\
\mathrm{L}\end{array}$ & $\begin{array}{l}35- \\
55 \mathrm{~g} / \\
\mathrm{L}\end{array}$ & $\begin{array}{l}3.2-8.2 \\
\mathrm{mmol} / \mathrm{L}\end{array}$ & $\begin{array}{l}53-97 \\
\text { umol/L }\end{array}$ & $\begin{array}{l}130- \\
175 \mathrm{~g} / \mathrm{L}\end{array}$ & $\begin{array}{l}2.08-2.65 \\
\mathrm{mmol} / \mathrm{L}\end{array}$ & $\begin{array}{l}0.78-1.65 \\
\mathrm{mmol} / \mathrm{L}\end{array}$ \\
\hline $\begin{array}{l}2014 / \\
10 / 31\end{array}$ & 2.9 & 11.1 & 1.71 & 3.29 & 17.5 & 20 & $166 \uparrow$ & 121 & 69.6 & 44.1 & 6.6 & $154.8 \uparrow$ & 138 & 2.16 & $0.71 \downarrow$ \\
\hline $\begin{array}{l}2015 / \\
3 / 29\end{array}$ & 2.18 & & & & 12 & 15 & $262 \uparrow$ & 148 & 72.9 & 42.4 & $8.5 \uparrow$ & $139 \uparrow$ & 132 & 2.26 & $0.67 \downarrow$ \\
\hline $\begin{array}{l}2016 / \\
4 / 28\end{array}$ & 1.6 & 6.87 & 1.37 & 3.16 & & & & & & & & & & & \\
\hline $\begin{array}{l}2016 / \\
5 / 25\end{array}$ & & & & & 21.5 & 22.4 & $147.2 \uparrow$ & 149.9 & 64.9 & 41.9 & $9.74 \uparrow$ & $180.5 \uparrow$ & & 2.19 & $0.62 \downarrow$ \\
\hline $\begin{array}{l}2016 / \\
6 / 15\end{array}$ & & & & & 21 & 23 & $144 \uparrow$ & 152 & 76 & 50 & $10.9 \uparrow$ & $175 \uparrow$ & & 2.4 & $0.62 \downarrow$ \\
\hline $\begin{array}{l}2016 / \\
9 / 7\end{array}$ & 1.82 & & & & $80 \uparrow$ & $60 \uparrow$ & $173 \uparrow$ & 173 & 72 & 52 & & $155 \uparrow$ & 133 & & \\
\hline $\begin{array}{l}2016 / \\
12 / 15\end{array}$ & 2.41 & 9.17 & 1.29 & 3.64 & 37 & 33 & $162 \uparrow$ & 142 & 74.7 & 47.2 & & $197 \uparrow$ & 127 & 2.1 & \\
\hline $\begin{array}{l}2017 / \\
1 / 5\end{array}$ & 2.43 & 11.1 & 1.7 & 3.74 & 39 & 34 & $149 \uparrow$ & 140 & $83.7 \uparrow$ & 50.3 & $9.23 \uparrow$ & $252 \uparrow$ & & & \\
\hline $\begin{array}{l}2017 / \\
1 / 19\end{array}$ & & & & & 38 & 38 & $161.7 \uparrow$ & 157 & 79 & 52.5 & $9.0 \uparrow$ & $234 \uparrow$ & 123 & 2.5 & $0.7 \downarrow$ \\
\hline $\begin{array}{l}2017 / \\
2 / 17\end{array}$ & & & & & $49 \uparrow$ & $44 \uparrow$ & & & 80 & 51.5 & $10.8 \uparrow$ & $194 \uparrow$ & 123 & 2.8 & $0.74 \downarrow$ \\
\hline $\begin{array}{l}2017 / \\
5 / 3\end{array}$ & & & & & 35 & $38 \uparrow$ & & 161 & 78.7 & 47 & $9.7 \uparrow$ & $192 \uparrow$ & & 2.33 & 0.98 \\
\hline $\begin{array}{l}2017 / \\
12 / 20\end{array}$ & 1.81 & 11.1 & 1.7 & 3.74 & & & & & & & & & 143 & & \\
\hline $\begin{array}{l}2018 / \\
11 / 19\end{array}$ & 2.13 & & & & 26 & 30 & $139 \uparrow$ & 170 & 76.5 & 50.9 & $9.5 \uparrow$ & $148 \uparrow$ & 148 & 2.48 & $1.95 \uparrow$ \\
\hline $\begin{array}{l}2019 / \\
3 / 11\end{array}$ & 1.75 & & & & 24 & 19 & 99 & 186 & 73.2 & 44.9 & $10.1 \uparrow$ & $155 \uparrow$ & & & \\
\hline
\end{tabular}


patient had a history of chronic hepatitis B infection, and had received lamivudine at $100 \mathrm{mg} /$ day for 19 years, then changed to $10 \mathrm{mg} /$ day of ADV owing to lamivudine resistance in 2009. After ADV treatment, his liver function was restored.

Based on the special situation of the patient, a multidisciplinary consultation discussion was conducted in Peking University First Hospital. During the discussion, doctors differentiated diseases according to their specialty, but could not identify the real cause of the bone pain. Based on the clinical pain manifestations, doctors were suspicious of bone tumors and myeloma, neglecting the possible effects of drugs. Elevated levels of penzymes also led doctors to suspect that the patient had a metastatic tumor, while negative monoclonal antibodies in protein electrophoresis excluded the diagnosis of myeloma. As the clinical diagnosis evidence was insufficient, the patient underwent relevant examinations to further confirm whether his bone pain was caused by a bone-related disease. Neither the patient's test results nor the results of gene screening confirmed bone or cancer-related diseases. On the basis of the medical history and laboratory examinations, the clinical pharmacist suggested a clinical diagnosis of ADV-induced hypophosphatemic osteomalacia due to acquired renal Fanconi syndrome, which was ignored by doctors. The relevant clinical manifestations and diagnostic basis for this patient can be seen in Table 4 .

Clinical pharmacists paid attention to the situation of drug treatment, and suggested that the bone pain might be a result of drug-induced adverse reactions. Based on the WHO Collaboration Center for International Drug Monitoring (The Uppsala Monitoring Centre) [10] method, the causal relationship of ADR in this case was probable/likely. ADR probability score using Naranjo's algorithm [11] was 7 points, which is determined as "probable/likely" (5-8 points), as shown in Supplementary Table 1 . In addition, preventability assessment using Hallas criteria [12] suggested that it was possibly avoidable. The prescription was not erroneous, but the ADR could have been avoided by an effort exceeding the obligatory demands.

In this case, after the adjustment of anti-HBV drug treatment scheme, the trend of creatinine elevation in the patient was reversed and gradually decreased, but the symptoms of bone pain did not disappear immediately. Bone pain began to relieve after 2 months and disappeared in May 2017. Four months after the discontinuation of ADV and during the 2-year follow-up, the patient's serum phosphate normalized, and creatinine levels decreased (Fig. 2). Bone pain also disappeared, and his walking ability improved significantly. The dramatic clinical and laboratory improvement observed after ADV discontinuation further supported the diagnosis of ADV-induced hypophosphatemic osteomalacia and renal impairment.

\section{Discussion and conclusions}

Although clinical studies have shown that ADV is generally well tolerated at $10 \mathrm{mg}$ daily with no evidence of proximal renal tubular dysfunction, our case and other studies suggest that actual incidence of ADV-induced hypophosphatemic osteomalacia and renal Fanconi syndrome may well be higher than previously thought.

This paper reports a case of renal and bone damage caused by ADV but misdiagnosed as bone tumors. Progressive bone pain and fracture and abnormal PET-CT are the main reasons for the oncologists suspecting bone tumor. The important of multidisciplinary cooperation and the role of pharmacist in diagnosis and prevention of drug adverse reactions is highlighted in this case.

Table 4 Relevant clinical manifestations and diagnostic basis of bone tumor, myeloma and adverse drug reactions for this patient

\begin{tabular}{|c|c|c|c|c|}
\hline Diagnostic Criteria & Bone tumor & Myeloma & Adverse Drug Reactions & Patient's condition \\
\hline Pain, swelling or mass & + & + & + & + \\
\hline \multicolumn{5}{|l|}{ Systemic symptoms } \\
\hline (anemia, progressive emaciation, insomnia, irritability, ect & + & + & + & + \\
\hline hepatomegaly & - & + & - & - \\
\hline renal failure & - & + & + & + \\
\hline Lymphadenopathy & - & + & - & - \\
\hline Pathological fracture & + & + & + & + \\
\hline Bone mineral density examination & - & + & + & + \\
\hline Protein electrophoresis monoclonal antibody & + & + & - & - \\
\hline \multicolumn{5}{|l|}{$\mathrm{PET} / \mathrm{CT}$} \\
\hline Skeletal abnormalities in different parts of the body & + & - & + & \pm \\
\hline Mainly abnormal lumbar spine & - & + & + & \pm \\
\hline Pathological section & - & - & - & - \\
\hline
\end{tabular}

Note: + means yes, - means no, \pm means hard to be sure or negative,? Means that the situation is unknown 

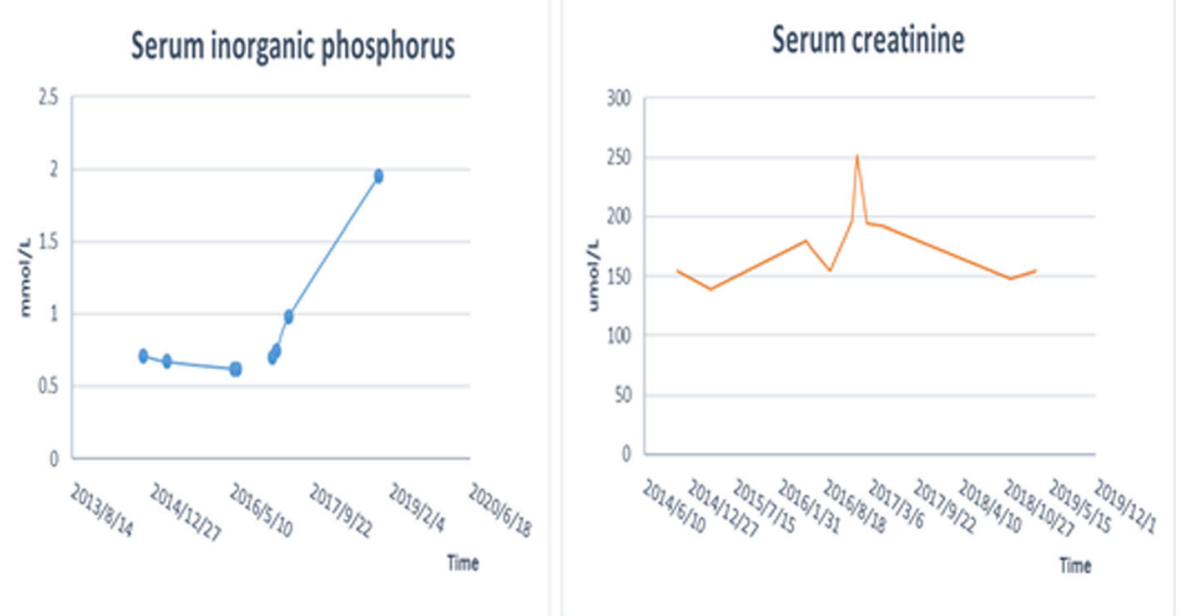

Fig. 2 Trend chart of patient's serum phosphate and creatinine levels from 2013 to 2019

During the whole course of the patient's medical treatment, the oncologists' unfamiliarity with adverse reactions to anti-HBV drugs were the main reason for the long-term exposure to the drug and the adverse reaction experienced by the patient.

\section{Drug-induced Fanconi syndrome}

Antiviral drugs are the main cause of Fanconi syndrome. Nucleoside reverse transcriptase inhibitors lead to kidney proximal tubule poisonousness, but it has a higher incidence with the nucleotide reverse transcriptase inhibitors. It might due to the high levels of uptake of these drugs into the proximal tubule cells. Although it is not clear about the mechanism of ADV nephrotoxicity, a likely hypothesis of drug-induced Fanconi syndrome has been proposed [13]. The human organic anion transporter-1 has been demonstrated to mediate the active uptake of ADV from blood into proximal tubular cells [14]. The clinical usage of adefovir and cidofovir has been limited for the nephrotoxicity, and they are known as established causes of Fanconi syndrome [15]. The newer agents with less nephrotoxic, tenofovir and entecavir, and are now the first-line therapy for hepatitis
B infection. The recommended dosage of antiviral drugs for different renal impairments, according to the pharmaceutical's instructions, can be seen in Table 5 .

Adefovir is dose-dependent with nephrotoxicity, resulting in renal phosphate consumption and osteomalacia [16]. Osteomalacia is a metabolic bone disease characterized by changes in bone mineralization. Electrolyte abnormalities and osteopenia always lead to muscle weakness, bone pain, fatigue, and pseudofractures found in osteomalacia. Pain start with weight-bearing sites, then spreads to the entire body. Factors identified as predictive of kidney damage and Fanconi syndrome [17] include: age over 40 years, rural environment, renal injury, eGFR $<90 \mathrm{ml} / \mathrm{min} / 1.73 \mathrm{~m}^{2}$, hypertension, diabetes, cirrhosis, and ADV treatment exceeding 24 months. Many cases of hypophosphatemic osteomalacia induced by low-dose adefovir ( $10 \mathrm{mg}$ daily) have been reported $[6,7]$, especially in Asian countries [18-20].

\section{Multidisciplinary teams}

Disease assessment and management requires complex clinical decision-making, and MDTs participation is encouraged to ensure that a range of professionals with

Table 5 Recommended doses of antiviral drugs for different renal impairments

\begin{tabular}{|c|c|c|c|c|}
\hline \multirow[t]{2}{*}{ Antiviral drugs } & \multicolumn{3}{|c|}{ Creatinine clearance rate $(\mathrm{mL} / \mathrm{min})$} & \multirow[t]{2}{*}{ Hemodialysis } \\
\hline & $\geq 50$ & $30-49$ & $10-29$ & \\
\hline Lamivudine & $100 \mathrm{mg}$ qd & - & - & - \\
\hline Adefovir Dipivoxil & $10 \mathrm{mg} \mathrm{qd}$ & $\begin{array}{l}10 \mathrm{mg} / 48 \mathrm{~h} \\
(20-49)\end{array}$ & $\begin{array}{l}10 \mathrm{mg} / 72 \mathrm{~h} \\
(10-19)\end{array}$ & $10 \mathrm{mg} / 7$ days \\
\hline Entecavir & $1 \mathrm{mg}$ qd & $0.5 \mathrm{mg} \mathrm{qd}$ & $\begin{array}{l}0.3 \mathrm{mg} \text { qd or } \\
0.5 \mathrm{mg} / 48 \mathrm{~h}\end{array}$ & $\begin{array}{l}0.1 \mathrm{mg} \mathrm{qd} \text { or } \\
0.5 \mathrm{mg} / 72 \mathrm{~h}\end{array}$ \\
\hline Tenofovir Disoproxil Fumarate & $300 \mathrm{mg}$ qd & $300 \mathrm{mg} / 48 \mathrm{~h}$ & $300 \mathrm{mg} /(72-96 \mathrm{~h})$ & $300 \mathrm{mg} / 7$ days \\
\hline Telbivudine & $600 \mathrm{mg}$ qd & $600 \mathrm{mg} / 48 \mathrm{~h}$ & $600 \mathrm{mg} / 72 \mathrm{~h}$ & $600 \mathrm{mg} / 96 \mathrm{~h}$ \\
\hline
\end{tabular}


different professional knowledge provide timely and appropriate care [21]. MDT meetings can be defined as regular discussions of patients, including professionals from different disciplines, such as such as surgeons, radiologists, pathologists, nurse specialists, pharmacists, and other health disciplines [22]. In this case report, from 2014 to 2017, the patient suffered from bone pain, sought medical treatment across the country, and experienced pain, which he described as 'physical torture', while the economic losses of the patients in the health service accumulated to 300,000 RMB. If MDT meetings were involved in the treatment in 2014, and dosage of ADV was adjusted timely, the patient would have avoided physical pain and personal economic loss for the next 3 years. The patients said that the bone pain gradually disappeared, the quality of life significantly improved, and also saved a lot of medical costs after the medication adjustment.

Fanconi syndrome with osteomalacia can be obtained from patient taking a low dosage $(10 \mathrm{mg} /$ day $)$ of ADV. Chronic hepatitis B patients taking ADV (10 mg/day) for long periods of time should pay attention to bone pain and renal function, and regularly monitor indicators of serum ALP, serum phosphorus, serum calcium levels, and bone metabolism markers. Patients with pre-existing renal insufficiency should monitor more frequently. Once ADR is suspected, ADV must be stopped immediately and carried out symptomatic treatment. Similarly, it also requires the differential diagnosis of calcaneal-associated diseases and tumors to prevent misjudgments and affect the diagnosis, treatment, and quality of life of patients.

This case indicates that differential diagnosis of calcaneal-related diseases and tumors is needed to prevent misjudgments and affect the diagnosis, treatment, and quality of life of patients. This case highlights the importance of ADR as a differential diagnosis and the need of pharmacists with drug safety expertise expert in the patient management.

\section{Supplementary information}

Supplementary information accompanies this paper at https://doi.org/10. 1186/s40360-020-00421-6.

Additional file 1: Table S1 ADR probability scale using Naranjo's algorithm

\section{Abbreviations}

ADV: Adefovir dipivoxil; ALP: Alkaline phosphatase; BMD: Bone mineral density; HBV: Hepatitis B virus; hOAT1: Human organic anion transporter-1; PET/CT: Positron emission tomography combined with a computed tomography; MyD88: Myeloid differentiation factor 88; MDT: Multidisciplinary team

Acknowledgements

Not applicable.

\section{Authors' contributions}

QX, ZL, HZ, QFX, GM, JZ, XC, and YC analyzed and interpreted the patient data regarding the disease and the analysis. $Y Y$ participated in the diagnosis and treatment of the patient. QX and ZL performed the histological examination of the kidney and pain of bone, and were a major contributor in writing the manuscript. All authors read and approved the final manuscript.

Funding

Not applicable.

Availability of data and materials

All data analyzed during this study are included in this published article.

Ethics approval and consent to participate

Not applicable.

\section{Consent for publication}

Written informed consent was obtained from the patient for publication of this case report and any accompanying images. A copy of the written consent is available for review by the Editor of this journal.

\section{Competing interests}

The authors declare that they have no competing interests.

\section{Author details}

${ }^{1}$ Department of Pharmacy, Peking University First Hospital, No. 6, Dahongluochang Street, Xicheng District, Beijing 100034, China. ${ }^{2}$ School of Pharmaceutical Sciences, Peking University Health Science Center, Beijing, China. ${ }^{3}$ Department of Infectious Disease, Peking University First Hospital, Beijing, China. ${ }^{4}$ Nuclear Medicine Department, Peking University First Hospital, Beijing, China. ${ }^{5}$ Department of Hematology, Peking University First Hospital, No. 6, Dahongluochang Street, Xicheng District, Beijing 100034, China.

Received: 3 December 2019 Accepted: 26 May 2020

Published online: 05 June 2020

\section{References}

1. World Health Organization. Global hepatitis report, 2017. Geneva: World Health Organization; 2017.

2. European Association for the Study of the Liver. EASL 2017 clinical practice guidelines on the management of hepatitis B virus infection. J Hepatol. 2017:67:370-98.

3. Chen YC, Su YC, Li CY, Wu CP, Lee MS. A nationwide cohort study suggests chronic hepatitis $B$ virus infection increases the risk of end-stage renal disease among patients in Taiwan. Kidney Int. 2015;87:1030-8.

4. Kim YJ, Cho HC, Sinn DH, Gwak GY, Choi MS, Koh KC, et al. Frequency and risk factors of renal impairment during long-term adefovir dipivoxil treatment in chronic hepatitis B patients. J Gastroenterol Hepatol. 2012;27. $306-12$

5. Chen N, Zhang JB, Zhang Q, Zhao YP, Li LY, Liu LW, et al. Adefovir dipivoxil induced hypophosphatemic osteomalacia in chronic hepatitis B: a comparative study of Chinese and foreign case series. BMC Pharmacol Toxicol. 2018;19(1):23.

6. Minemura M, Tokimitsu Y, Tajiri K, Nakayama Y, Kawai K, Kudo H, et al. Development of osteomalacia in a post-liver transplant patient receiving adefovir dipivoxil. World J Hepatol. 2010;2:442-6.

7. Fabbriciani G, de Socio GV, Massarotti M, Ceriani R, Marasini B. Adefovir induced hypophosphatemic osteomalacia. Scand J Infect Dis. 2011;43:990-2.

8. Kunii T, lijima T, Jojima T, Shimizu M, Kase M, Sakurai S, et al. Denosumab improves clinical manifestations of hypophosphatemic osteomalacia by adefovir-induced Fanconi syndrome: a case report. J Med Case Rep. 2019. 13(1):99.

9. Park S, Kim WI, Cho DH, Kim YJ, Kim HS, Kim JH, et al. Adefovir-induced Fanconi syndrome associated with osteomalacia. Clin Mol Hepatol. 2017; 24(3):339-44.

10. The Uppsala Monitoring Centre (the UMC). The use of the WHO-UMC system for standardized case causality assessment. https://www.whoumc. org/media/164200/who-umc-causality-assessment_new-logo.pdf, 2018-4-6/ 2018-12-11. 
11. Naranjo CA, Busto U, Sellers EM, Sandor P, Ruiz I, Roberts EA, et al. A method for estimating the probability of adverse drug reactions. Clin Pharmacol Ther. 1981;30(2):239-45.

12. Hallas J, Harvald B, Gram LF, Grodum E, Brosen K, Haghfelt T, et al. Drug related hospital admissions: the role of definitions and intensity of data collection, and the possibility of prevention. J Intern Med. 1990;228(2):83-90.

13. Wu C, Zhang H, Qian Y, Wang L, Gu X, Dai Z. Hypophosphatemic osteomalacia and renal Fanconi syndrome induced by low-dose adefovir dipivoxil: a case report and literature review suggesting ethnic predisposition. J Clin Pharm Ther. 2013;38:321-6.

14. Servais A, Lechat P, Zahr N, Urien S, Aymard G, Jaudon MC, et al. Tubular transporters OAT1 and MRP2 and clearance of adefovir. Nephrol Ther. 2005; 1:296-300.

15. Vigano M, Lampertico P, Colombo M. Drug safety evaluation of adefovir in HBV infection. Expert Opin Drug Saf. 2011;10:809-18.

16. Kimdu H, Sung DH, Min YK. Hypophosphatemic osteomalacia induced by low-dose adefovir therapy: focus on manifestations in the skeletal system and literature review. J Bone Miner Metab. 2013;31(2):240-6.

17. Lin $Y$, Pan F, Wang Y, Chen Z, Lin C, Yao L, et al. Adefovir dipivoxil-induced Fanconi syndrome and its predictive factors: a study of 28 cases. Oncol Lett. 2017;13(1):307-14.

18. Lin J, Zhuo Y, Zhang D. Nephrolithiasis and Osteomalacia associated with adefovir-induced Fanconi syndrome in a patient with hepatitis B. BMC Nephrol. 2017;18(1):275.

19. Qian YY, Dai ZJ, Ruan LY, Pan YJ, Jin J, Shi MT, et al. Low-dose adefovir dipivoxil-induced hypophosphatemia osteomalacia in five chronic hepatitis B virus-infected patients. Is low-dose adefovir dipivoxil-induced nephrotoxicity completely reversible? Drug Des Devel Ther. 2019;13:1127-33.

20. Jia HY, Ding F, Chen JY, Lian JS, Zhang YM, Zeng LY, et al. Early kidney injury during long-term adefovir dipivoxil therapy for chronic hepatitis B. World J Gastroenterol. 2015;21(12):3657-62.

21. Taylor C, Munro AJ, Glynne-Jones R, Griffith C, Trevatt P, Richards M, et al. Multidisciplinary team working in cancer: what is the evidence? BMJ. 2010 340:с951.

22. Kurpad R, Kim W, Rathmell WK, Godley P, Whang Y, Fielding J, et al. A multidisciplinary approach to the management of urologic malignancies: does it influence diagnostic and treatment decisions? Urol Oncol Semin Orig Invest. 2011;29(4):378-82.

\section{Publisher's Note}

Springer Nature remains neutral with regard to jurisdictional claims in published maps and institutional affiliations.

Ready to submit your research? Choose BMC and benefit from:

- fast, convenient online submission

- thorough peer review by experienced researchers in your field

- rapid publication on acceptance

- support for research data, including large and complex data types

- gold Open Access which fosters wider collaboration and increased citations

- maximum visibility for your research: over $100 \mathrm{M}$ website views per year

At $\mathrm{BMC}$, research is always in progress.

Learn more biomedcentral.com/submissions 